\title{
RASTROS DO SAGRADO NO MUNDO CONTEMPORÂNEO: REFLEXÕES
}

Traces of the Sacred in the Contemporary World: considerations

Emerson José Sena da Silveira ${ }^{1}$ UFJF - Minas Gerais/ Brasil

RESUMO: Pretendo apresentar neste artigo reflexões sobre um conceito central das Ciências da Religião e da Teologia, o conceito de sagrado. Contudo, não apresentarei uma discussão conceitual a partir de autores consagrados, mas partirei da indagação sobre as percepções do sagrado e seus significados no mundo contemporâneo, dando foco à sociedade brasileira. Partindo dessa pergunta, e embasado em metodologia qualitativa, faço um percurso de visitações a autores clássicos das Ciências Humanas conjugados com exemplos contemporâneos em um estilo mais literário e ensaístico, embora com rigor reflexivo científico-acadêmico.

Palavras-chave: Sagrado. Contemporaneidade. Ciências da Religião. Teologia.

ABSTRACT: In this article I intend to present considerations on a central concept of the Sciences of Religion and Theology: the concept of the sacred. However, I do not propose a conceptual discussion based on the works of established authors, rather questioning the perceptions about the sacred and its meanings in the contemporary world instead, focusing my analysis on the Brazilian society. Based on this question, and based on a qualitative methodology, I round-up the works of classic authors of the Human Sciences, associated with contemporary examples in a more literary and essayist style, although with scientific rigour.

Keywords: Sacred. Contemporaneity. Sciences of Religion. Theology.

\footnotetext{
${ }^{1}$ Professor do Programa de Ciências da Religão da Universidade Federal de Juiz de Fora, Antropologo . E-mail: emerson.silveira@ufjf.edu.br
} 
Introdução

No mundo moderno-contemporâneo, marcado pela aceleração tecnológica, por antigos e novos modos de produção, por redes de mídia e consumo, por intensa subjetivação, por individualismos (romântico, possessivo, estético, midiático), por trânsitos religiosos e migrações socioeconômicas, faz algum sentido os sentidos tradicionais do conceito de sagrado? Se faz algum sentido, quais são eles? Não estaria o conceito de sagrado vivendo uma crise representacional, ou seja, perdeu a capacidade de interpretar reais situações vividas por indivíduos, igrejas, templos, terreiros, lojas, grupos e instituições, no âmbito da religião, em seu cotidiano, em nossa época de torvelinhos, terrorismos e colapso entre mundo online e offline, espetáculo e consumo irrestrito? Com este texto, não pretendo dar uma resposta geral, mas lançar provocações para fazer brotar pistas de compreensão das intrincadas teias do "sagrado" na sociedade moderno-contemporânea. Adiantando algumas hipóteses, proponho que, na estrutura contemporânea da vida humana, assoma ao horizonte uma crise hermenêuticorepresentacional do conceito de sagrado. Enfraquecido, a operação conceitual baseada na ideia de sacro $^{1}$ dificulta pensar o conjunto dos fenômenos que envolvem as religiosidades e espiritualidades, institucionais e não-institucionais, na atualidade em especial, em sociedades como a brasileira, que mistura agendas atávicas e tecnológicas. Por isso, um dos desafios da análise do sagrado nas sociedades contemporâneas é a compreensão dos seus contornos, implicações e interpelações diante de outros sistemas cognitivos e sociais que emolduram a convivência entre homens e instituições, entre comunidades e fluxos globais de consumo e tecnologia. Para avançar algumas hipóteses qualitativas, farei uma reflexão teórica, ao estilo ensaístico, calcada em revisão parcial de literatura das Ciências Sociais e da Ciência da Religião, com algumas ilustrações empíricas, entrelaçando linhagens teóricas interpretativas afim de pensar o fôlego hermenêutico de alguns aspectos do conceito de sagrado, tal como legado às Ciências da Religião.

1 Há uma grande multiplicidade de significados do termo que a pesquisa de Agamben (2011) revisita. No entanto, por questões de espaço, limitarei o espectro conceitual às acepções mais comuns na área acadêmico-científica de Ciências da Religião e Teologia, e, ainda assim, o texto não exporá todas as implicações relativas às conceituações dos grandes autores clássicos, como Rudolf Otto. 
Visitações do sagrado

O termo "sagrado" permanece como totem para alguns grupos de pesquisadores e como artefato arqueológico para outros. Por uns é adorado, por outros é repelido, mas quase sempre é visto como que "andando" entre os homens e mulheres, como se fosse uma realidade por si só, independente, acima e além das histórias das sociedades e culturas, uma chave hermenêutica geral que torna compreensível qualquer fenômeno religioso ou espiritual. Mas, todo conceito que pretenda ou que seja usado para explicar todas as realidades termina por não explicar nada, porque encontra-se banalizado, torna-se um discurso ideológico de segundo grau, legitimador e manipulador de algum valor, instituição, ideia ou estrutura social (FOUREZ, 1985).

O sagrado, em uma perspectiva da filosofia da ciência, assim como o fenômeno econômico, o psíquico, o sociológico e o religioso, é um falso objeto empírico, aqueles que só existem enquanto tais pela ação dos homens e mulheres (FOUREZ, 1995). Por isso, não existe um conceito dado de uma vez, caído dos céus límpidos, natural em si mesmo e que não dependa dos paradigmas constitutivos de uma disciplina ou de uma ciência em determinada época, e que não sofra mudanças, alterações ou declínios (FOUREZ, 1995). Dessa forma, ao lidar com o sagrado, entendido como sistema organizado de crenças, práticas, comportamentos socialmente estruturados, por um lado, ou como vivências e experiências atreladas a uma dimensão “sobrenatural”, "mística', transcendental", por outro, é preciso abandonar a ideia de uma muralha sólida, homogênea e sem aberturas.

Alguns dizem ter visto o sagrado lançando flertes com a cultura de consumo ou navegando nas redes eletrônicas; outros dizem que se escondeu na utopia biogenética da saúde e bioengenharia; ou ainda, viram-no entrando e saindo em rituais mágicos e religiosos contemporâneos, a torto e a direito, em todas as famílias religiosas, dentro de templos monumentais, barracões de zinco ou shoppings centers, nas ruas, em marchas cristológicas triunfais e conservadoras. Juram que ao seu encalço, saem esbaforidos, caçadores de borboletas com finas redes epistemológicas ou hackers antenados, com criptografias e bytes místicos.

Todavia, na rotina moderna, instalaram-se novas dinâmicas de resistências, criações e invenções discursivas com o seguinte horizonte: universalização dos meios de produção capitalista mercantil e infraestrutura pública; constituição de novos circuitos e mercados de bens 
e serviços (emergências dos mercados simbólicos); emergência de intelectualidades (religiosas e não religiosas) paralelas à universidade com possibilidade de apropriação tecnológica (software livre, códigos abertos, cultura digital). Quem trabalha com o conceito tradicional de sagrado se depara, se vê envolvido, enredado, engabelado por essas novas estruturas que delineei acima. A crise conceitual brota quando ocorre a sutil transformação do sujeito gramatical - o sagrado é o que provoca horror, pavor, êxtase, choque, volúpia, fascinação - em sujeito ontológico. Em outras palavras, o sagrado, ao tornar-se universal, projeta-se como uma nova metafísica, uma instância absoluta, salva das flutuações e dos deslizamentos dos tempos e histórias, emanando, portanto, da dimensão do real conhecimento.

Mas, diante do tiroteio de fenômenos empíricos e das disputas semânticas entre especialistas e estudiosos, teima em permanecer, uma pergunta: o termo "sagrado" ainda tem fôlego hermenêutico para compreender a contemporaneidade dos fenômenos que remetem às múltiplas dimensões do que é chamado "transcendente", "numinoso", “espiritual”, "invisível”, "sobrenatural", de "outros mundos"? Quando o mercado, o consumo, o shopping center e o videogame são vistos como símbolos e/ou locais do novo sagrado na sociedade capitalista, em oposição ao velho sagrado (as liturgias religiosas, os cantos, as rezas e orações), o que é sagrado, o que é profano? Nesse sentido, falar em sagrado é também falar sobre o profano. Mas, em um mundo em que as fronteiras entre sexualidades, religião, gênero, política, mídias e subjetividade estão viradas pelo avesso, deslocadas, ressignificadas, onde estão os limites conceituais entre os dois termos [sagrado e profano]?

É difícil tomar esses termos [sagrado/profano] entre as mãos, deixá-los fluir entre os lábios e estalar nas palavras, pois são ambíguos em sua ossatura epistêmica mais fundamental. Ambos supõem tanto separação quanto contato; tanto vertigens endoidecidas quanto disciplinas pétreas. Nos dois termos, um par de opostos complementares, cabem sentidos ambíguos e paradoxais.

Durkheim (2006) afirmou que, na origem do sagrado, está o social, a sociabilidade, o coletivo, que são fontes de legitimidade fundamentais. A adoração de um totem, a celebração festiva que excitam as tribos, é a projeção de complexos mecanismos simbólicos coletivos que fixam sentidos religiosos nos signos sociais (DURKHEIM, 2006). O imanente social seria a 
fonte das transcendências, êxtases, transes, cultos, totens, enfim, a origem de tudo o que transporta o homem de sua realidade cotidiana, individual, para uma outra dimensão mais energética, uma dimensão fundadora e original (DURKHEIM, 2006). A religião, com as mitologias e rituais articulados entre si, derivaria dessa dimensão originária como memória do evento e da emoção original que se perpetua no decorrer da vida social (DURKHEIM 2006). Dessa forma, desde as tribos mais agrestes dos rincões africanos, asiáticos e australianos até movimentos revolucionários e proclamações civis entusiásticas no coração das terras europeias, o sagrado assume novos formatos e possibilidades de existência (DURKHEIM, 2006).

Porém, o problema hermenêutico, ainda não resolvido, foi lançado pela fenomenologia da religião, abordagem dominante na fase inicial da Ciência da Religião, logo após da sua institucionalização em universidades europeias (USARSKI, 2004). O clássico estudo de Rudolf Otto (1985) balizou e baliza a reflexão de muitos pesquisadores e trabalhos. Permanecem, todavia, as polêmicas com relação ao alcance, sentido e significado do conceito.

Segundo Usarski (2004), em artigo pouco citado no âmbito das ciências da religião e das ciências sociais, os conflitos entre métodos, vividos na Europa e EUA durante os anos setenta do século XX, diminuiu a influência do paradigma fenomenológico, embora o processo tenha variado de acordo com os contextos nacionais e os graus de institucionalização das ciências da religião em cada região. Houve, e ainda há, negligência em relação ao "contexto sócio-histórico em que o termo [sagrado] ganhou importância" e em relação à "desatenção diante das implicações substanciais que delimitam sua validade como conceito no âmbito da Ciência da Religião" (USARSKI, 2004, p. 78).

O Das Heilige [O Sagrado] foi publicado em 1917, em plena Primeira Guerra Mundial, num contexto de fortes desesperos, de recuo da ideologia do liberalismo democrático clássico diante das ideologias fascistas, nazistas e comunistas, de fortes movimentos artísticos, anarquismos e algumas reflexões clássicas da sociologia, da história, da psicologia e da antropologia, realizadas entre os anos 1900 e 1920. Na arguta crítica de Usarski (2004, p. 7980),

A referência não-refletida do termo é ainda mais problemática em função da displicência face à afinidade do conceito de sagrado com um tipo específico de religiosidade resultante da origem familiar e socialização primária dos precursores e pioneiros da Fenomenologia da Religião. Mais concretamente falando, é o 'esquema protestante' no sentido da relação imediata do ser humano diante do 'seu' Deus que constitui o padrão básico de todas as interpretações do termo. 
Avanço as suspeitas sobre o conceito clássico de sagrado além da crítica de Usarski (2004): talvez sua gênese e seus usos modernos, em parte dos estudos contemporâneos feitos pelas ciências da religião e da teologia, estejam relacionados a uma nostalgia ou saudade da metafísica ontológica clássica, duramente criticada desde o final do século XIX pela Filosofia e pelas Ciências Humanas e Sociais (História, Sociologia, Antropologia, Ciência Política, Psicologia, Geografia). Assim, diante de fluxos incessantes das identidades, a ideia de um território semântico seguro volta a ganhar crédito e a ser objeto de forte desejo.

A antiga metafísica, desde seus primórdios platônicos, estabeleceu um domínio do Ser que, pairando acima das mudanças [pistis, eikasia, doxa, dimensão das formas primeiras], foi defendido como um "porto hermenêutico seguro" [noesis, dianoia, dimensão das coisas visíveis, dos reflexos, das imagens] diante dos mares de Heráclito, o filósofo grego a quem se atribui os primeiros lampejos da concepção dialética da realidade. É importante observar que a ancoragem do conceito de sagrado foi realizada na tradição da Parmênides e de Platão, e não na de Heráclito, Hegel e Marx.

Ao longo da história, a metafísica encarnou-se em diversas doutrinas, em especial, nas oriundas do Cristianismo [tomismo, o agostinismo], permanecendo como um apelo do Ser no oceano agitado das coisas e dos corpos. Foi também ao longo do tempo que nasceram críticas aos postulados metafísicos, desde o medievo (Guilherme de Ockham e sua famosa experiência lógica, a navalha: "não se devem multiplicar entes sem necessidade") até o mundo moderno (David Hume, Friedrich Nietzsche), prolongando-se com a modernidade tardia (Martim Heidegger).

Mas, as críticas linguísticas, histórico-comparativas e sócioconstrutivistas, feitas desde as primeiras décadas do século XX, convergem para uma constatação: a palavra 'heilig' [sagrado, em tradução livre] "não é universalmente traduzível, mas [...] desempenhou um papel particular conforme o consenso linguístico" ocorrido na primeira geração dominante de pesquisadores na Ciência da Religião (USARSKI, 2004, p. 81). Uma das mais sérias questões sobre os problemas do conceito de sagrado permanece em aberto: 
[...] enquanto a ciência é, por definição, um empreendimento público, portanto exotérico, os representantes da Fenomenologia da Religião exigem do leitor um acordo com seus procedimentos, substituem uma discussão metodológica séria por uma 'contemplação sobre o fenômeno' e omitem a questão chave: 'Como um observador distingue a religião de uma maneira que pode valer também para outros observadores e que se poderia distinguir de simples atitudes da fé?' (USARSKI, 2004, p. 94).

As distinções teoréticas do sagrado tornam-se difíceis dentro de um quadro teórico acadêmico-científico. Como interpretar a afirmação de Otto (1995) sobre a exigência de uma experiência do sagrado para uma compreensão mais profunda? O tempo da modernidademoderna, desde fins do século XIX até a segunda metade do século XX, caracterizou-se pela regência de monoteísmos metodológicos enquanto ícones de uma relação necessária e ontológica, entre uma ciência e seu método. Formaram-se, então, ciências e metodologias monoparadigmáticas, baseadas numa fidelidade monoteísta a um método que esculpiu a identidade pela qual foram conhecidas e se consagraram nas universidades. $\mathrm{O}$ exclusivismo metodológico dessa relação foi visto como uma das garantias, na ótica moderna, da imprescindível cientificidade de uma investigação empírica ou conceitual.

A configuração monoteísta do método na Ciência da Religião influenciou na forma como a categoria de sagrado, nascida entre a Teologia e a Filosofia, foi recepcionada, apropriada e formatada por pesquisadores em seus trabalhos de investigação. O paradigma fenomenológico disputou espaço, avançou em muitos terrenos e no Brasil insiste em permanecer como horizonte metodológico e interpretativo, mas sem revisões mais aprofundadas de suas origens e limitações histórico-comparativas.

O sagrado, enquanto categoria amorfa e universal, tornou-se peça de resistência para muitos teóricos contra o que foi chamado de arrogância epistêmica das ciências duras e modernas, institucionalizadas desde as grandes experiências de Galileu Galilei (século XVII). Por outro lado, é possível, dentro uma perspectiva construcionista oriunda da Filosofia e da História das Ciências, criticar o forte viés idealista-metafísico presente no interior das ambições positivistas-empiristas que avassalaram as investigações das hard-sciences, mas sem recorrer a conceitos totalizantes e totalitários (FOUREZ, 1995).

No mundo de redes, fluxos e refluxos, fundamentalismos seculares e religiosos, o religioso e o cultural estão amalgamados, os blocos monolíticos são desfeitos, o que impõe a 
necessidade de canais multivocais de diálogo entre perspectivas e tradições teóricas das diversas comunidades e instituições de pensadores, cientistas e intelectuais, para que seja construída uma ressignificação dos sentidos do conceito de "sagrado". Apenas como uma ilustração, apresento - como indício das imbricações contemporâneas que estão a exigir uma releitura conceitual uma sequência de propagandas de shows:

No mês de abril, Uberlândia vai receber o show do Padre Fábio de Melo que se apresentará no formato acústico, com a promessa de emocionar o público. $\mathrm{O}$ evento, realizado pela Livraria Aparecida em parceria com o Arroz Vasconcelos, acontece no dia 6/4, às 20h, no Center Convention. Com mais de 15 anos de carreira como músico, Padre Fábio de Melo possui 19 álbuns lançados e milhões de unidades vendidas no Brasil e no exterior. O show [...] faz parte da turnê para divulgar seu novo trabalho "O Sagrado dos Dias" [...]. (grifo meu). ${ }^{2}$

Conhecido por sua espiritualidade, canções, escritos, pregações que tocam a alma e leva-nos a um encontro pessoal com Deus, Padre Fábio de Melo é hoje um dos cantores conhecidos não só no meio católico. [...] no próximo dia 22 de junho ele fará uma apresentação em Divinópolis [...]. O show intitulado "Sagrado dos Dias" é diversificado, intimista e promete encantar a todos os presentes, assim explica o assessor e empresário Frederico Soares: "o show é composto pelo Padre e mais quatros músicos, na qual ele reúne grandes clássicos do MBP (música popular brasileira), músicas católicas e composições autorais que fizeram sucesso em sua carreira. ${ }^{3}$

Padre Fábio de Melo traz o show Solo Sagrado. [...]. Sua obra é composta por 6 livros e 11 CDs que, juntos, venderam mais de 4 milhões de unidades. Padre Fábio de Melo acredita que um bom evangelizador tem o poder, através das palavras, de conscientizar as pessoas para uma vida mais simples e confortável. Com fama de galã e assediado por onde passa, o padre afirma que não é vaidoso e que não sente falta das coisas que teve que abrir mão para ser padre. [...] ele afirma que não podemos dissociar a saúde espiritual da saúde do corpo e que os cuidados que temos com a alimentação e a prática de exercícios físicos repercute em nosso espiritual. ${ }^{4}$

2 Disponível em: http://g1.globo.com/minas-gerais/triangulo-mineiro/especial-publicitario/arrozvasconcelos/noticia/2017/03/padre-fabio-de-melo-faz-show-acustico-em-uberlandia.html. Acesso em: 25/05/2017.

3 Disponível em: http://www.mariadenazare.com/noticias/show-do-padre-fabio-de-melo-em-divinopolis/. Acesso em: 25/05/2017.

4 Disponível em: https://domushall.com.br/blog/padre-fabio-de-melo-na-domus/. Acesso em: 25/05/2017. 
O sagrado aparece como show: o espetáculo do sagrado, vendido, consumido, divulgado em canais religiosos e não-religiosos, institucionais e pessoais. $\mathrm{O}$ conceito tradicional de numinoso consegue dar conta, em termos de rendimento hermenêutico, dessas novas configurações, nascidas na modernidade tardia?

Nos trechos das propagandas acima, um agente profissional do sagrado, o padre, está em turnê, canta, dança [cantos sacros, cantos comuns], em espaços "profanos". Os títulos dos espetáculos do sacerdote produzem imagens díspares [solo sagrado e sagrados dos dias], alternando reminiscências que remetem à Bíblia e ao profano [a sarça ardente de Moisés e os dias que passam no simples cotidiano].

Mas que sagrado é esse o das propagandas de shows? O que atemoriza, provoca fascínio, pavor, desejo extático de fusão ou de efusão, diante do qual nenhuma palavra pode ser dita, apenas dançar? Há "sagrados" e "Sagrado"? Há religiões, por exemplo, em que o sagrado não é temor, transcendência terrífica ou encantamento radical, mas é expressão imanente, contida em gestos sem transcendência: atos ligados aos afazeres mais simples do dia a dia, como tomar uma xícara de chá, atos vividos em um rito decantado, alentado e delicado.

Um dos sentidos da palavra sagrado (apartado, separado) tem suas raízes fincadas no mundo indo-europeu, nascido de vivências históricas e culturais específicas (USARSKI, 2004). O apagamento das origens e dos rastros que mostram as "impurezas" histórico-sociológicas do conceito tornou-o aberto em demasia, colocando-o na posição de onisciência e, portanto, na posição de instância explicativa final objetos, relações e sujeitos religiosos e não-religiosos. 
O conceito onisciente foi projetado como índice universal por estudiosos da cultura semita e foi abraçado por filólogos, historiadores, sociólogos, teólogos e fenomenólogos, o que aumentou sua difusão e presença, em especial nos programas de graduação e pós-graduação em teologia e ciências da religião.

O conceito de numinoso, apresentado no livro Das Heilige, do teólogo e filósofo alemão Rudolf Otto (1985), tornou-se mensurador de um sem número de experiências do além e do aquém. Isso dá origem a um sério problema: a impossibilidade de se operar empiricamente um conceito teológico-filosófico. Em uma perspectiva mais historicista, é possível afirmar que o "sagrado" sempre trafega nos trilhos da História e da Cultura, das tradições e inovações religiosas. É veiculado, e inoculado nos - e pelos - desejos de homens e mulheres, ricos e pobres, das classes trabalhadoras e burguesas, das castas ou estamentos patrimoniais, dos grupos religiosos e não-religiosos.

A religião, nessa perspectiva, é pálido reflexo do sagrado selvagem que volta e meia espoca, reverbera e repercute no grito extático dos pentecostais, no rodopio sensual das pombagiras, no silêncio aveludado das iogas, no caleidoscópio psicodélico New Age, nos latinórios tradicionalistas, na cristalina mensagem dos espíritos aos médiuns, nas revelações do Espírito Santo, movendo os sapatinhos de fogo e correntes de prosperidade.

A autoevidência do religioso e do sagrado perdeu-se, precisando ser constantemente construída em meio aos eixos culturais, nos mais complexos enlaces: mídias de massa e cibernéticas, biotecnologias, neuro-psico-genéticas, ecologias e pobrezas econômicas, gêneros e moralidades diversas. Por suposto, nas sociedades modernas, a identidade religiosa ou espiritual de massas é um horizonte simbólico importante, mediado hoje por uma cultura do consumo, de origens românticas. As massas, classes e grupos sociais, apesar dos experimentalismos, não querem perder totalmente de vista a identidade normativa, e daí a resistência em negá-la ou vê-la denegrida por outros grupos sociais (TAYLOR, 2010).

O marco identitário normativo-ontológico ainda é importante na busca por âncoras sociais para o sagrado (TAYLOR, 2010). Mas, nesse espaço histórico contemporâneo, o sagrado permanece como categoria interpretativa, e não como conceito universal. Por isso o sagrado está dentro das promessas de salvação que embalam a moral conservadora de parlamentares cristãos, tornando-a um arbusto chamejante, diante do qual as sandálias das 
minorias sociais e sexuais devem ser postas de lado, pois não devem pisar o solo numinoso onde o Javé das maiorias brancas fulgura.

Há um viés político e de poder, pouco explícito, nas dimensões do sagrado, mas visível, por exemplo, nas linhas da atuação da frente parlamentar evangélica e dos seus cavalos de batalha: a definição de casamento heteronormativo e a recusa do casamento homoafetivo.

Mas, o sagrado é uma lâmina afiada com dois gumes, o impuro e o puro, a sombra e a luz, o verso e o reverso (DURKHEIM, 2012). O que para alguns grupos é o impuro pode ser o marginal ou aquilo que é forçado a ficar às margens. Em outras palavras, deuses e purezas terrestres e/ou celestiais de povos, tribos, grupos e etnias colonizadas ou submetidos a processos de exploração e espólio podem ser (re)apropriados e ressignificados pelas maiorias dominantes e metamorfosearem-se em demônios e impurezas que contaminam as corretas divisões hierárquicas, e, por isso, trazem perigo e riscos de abalos à ordem religiosa e simbólica, ao status quo.

Por outro lado, quando igrejas cristãs inclusivas, embora minoritárias, propõem releituras de passagens bíblicas e pautas políticas que defendem às minorias sexuais, os LBGTQs (Lésbicas, Gays, Bissexuais, Travestis, Transexuais/Transgêneros, Queers), mostram uma mutação dentro do conservadorismo monoteísta cristão. As igrejas cristãs inclusivas produzem, no mundo moderno-contemporâneo, uma abertura política por dentro de camadas e sedimentos acumulados de interpretações dominantes.

Por isso, um ponto importante na produção dos discursos religiosos minoritários e maioritários são os circuitos e os tráfegos simbólicos (transmissão, reprodução, continuidade e descontinuidade) de rituais e mitologias ligados às origens dos fundadores ou dos eventos fundadores do sagrado original que constituem a questão da memória do sagrado e a sua continuidade no tempo e no espaço. 
Assim, a cultura digital, o midiativismo e as estratégias de apropriação de ferramentas tecnológicas (Facebook, Twitter e outras), para causas e objetivos religiosos, implodem as distinções entre espaços culturais e religiosos, entre semânticas seculares e não seculares. Emergem e se adensam contaminações entre semânticas opostas, fecundando pensamentos religiosos e sociais com novas terminologias, territórios e fronteiras. Há contaminação, por um lado, com um longo desfile de rituais, mitos e cosmologias de purificação, exorcismo e afastamento; há contágios, por outro, com um rico cortejo de rituais, mitos e cosmologias do transe, possessão e êxtase que mesclam espaços e territórios religiosos e não-religiosos.

Nesse sentido, a globalização econômico-financeira, em compasso-descompasso com a globalização cultural, e os consequentes fluxos de signos e sentidos derramados sobre a religião, e desta para outras esferas do social, multiplicam precariedades sociais e existenciais, tornam trágicos os atos fundamentalistas, mas também geram novas dinâmicas de busca, resistência e vivência social e religiosa do sagrado, ou do que se pretenda como "sagrado".

Os conservadores old school e os novos conservadores no campo da religião e da sociedade, almejam reinventar antigas fronteiras e, em decorrência disso, recolocam o sagrado como uma entidade a-histórica, atemporal, acima das empirias e procuram a desejada terra prometida e segura da ordem e da hierarquia, exalando, assim, uma forte nostalgia da tradição. E o que se põem a fazer, favorecidos paradoxalmente com as novas mídias, a ampliação do espaço público e a laicidade estatal, é propor ações e projetos regressivos, a fim de reestabelecer ordenamentos sociais e eugenia simbólica, excluindo minorias e grupos sociais. Observe-se, entretanto, que as formas e velocidades de interpretação e de ação religioso-política variam enormemente. As variáveis socioculturais e biográficas (escolaridade, renda, região e outras) modulam ritmos de absorção, recusa, complementação, oposição e ressignificação de fronteiras e experiências espirituais entre grupos e famílias religiosas.

Nos novos contextos midiáticos-econômicos, as mesclas entre discursos operam freneticamente, aproximando cosmologias religiosas e morais. Em tal ambiente de fluxos, as religiões dissolvem-se em uma miríade de atores e discursos, mas ao mesmo tempo, galvanizam-se em redes e troncos, enfeixados por elementos discursivos comuns. Portanto, parece haver um processo de transversalização de tópicos discursivos que emergem em eventos, ações e falas de líderes e grupos religiosos. O sagrado circula, então, pelas frestas e interstícios 
sociais, em uma dupla dimensão, puro e impuro, divino e demoníaco, perante o qual adotam-se procedimentos de isolamento e segurança contra contágios, mas que sempre se mostram falhos e de pouca eficiência.

As religiosidades, dentro desse cenário, espocam, nos números declarados de crenças e práticas, trânsitos e fluxos entre religiões de origem/etnia e religiões de escolha/busca. Por outro lado; crenças e práticas religiosas repercutem para muito além de seu sítio original. Há católicos que acreditam em reencarnação e em horóscopo, apoiam o papa, mas usam métodos anticoncepcionais não-naturais (pílula e camisinha); há neopentecostais que exorcizam o demônio, passam debaixo do pano vermelho abençoado ou da toalhinha benta com o "suor" do apóstolo; há religião na busca da "pureza" nunca suficiente e inexistente.

No entanto, entre a emoção original, perdida na história (na horda primitiva ou no néocortex), e a atualidade do presente histórico, estende-se uma linha que, aos olhos dos religiosos, é contínua ou forçada a ser contínua (HERVIEU-LÉGER, 1993). A menos que outros grupos teçam e façam valer memórias heterodoxas, divergentes da linha ortodoxa, mas conectadas (ou vistas como ligadas) à emoção "primordial", pretensas linhagens religiosas "puras" tornam-se o establishment simbólico, religioso e social.

A religião, como fonte derivada do sagrado original, é trama de desejos e de palavras, enroscando vidas, escolhas, indivíduos e comunidades, entrelaçando política e consumo, marketing e dogma. Por isso, quem fala em religião, diz rito, mito e cosmologia, estruturas e presenças, diz linguagens e semânticas, também diz política para dentro e para fora do grupo, da família religiosa, da sociedade, do Estado.

Constitui-se a política como estratégia de aproximar aliados para a "causa" e para dividir (ou retirar do poder) os adversários da "causa" ou dela dissidentes. Qual a "causa"? A mais nobre, a de Deus, dos deuses, deusas e suas vontades onipotentes, pois apenas os pecadores e hereges não percebem, e, por isso, precisam ser salvos, mesmo que não queiram. Essas operações de submissão e subalternização são políticas, mas, ao mesmo tempo, não são reconhecidas como tecnologias de poder, porque são vistas por grupos conservadores como emanações do sagrado eterno.

Porém, na alta modernidade ou hipermodernidade, as fronteiras das identidades (religiosas, políticas, sociais, estéticas) tornaram-se móveis (metáforas e performances, construtos a exigir plausibilidade) (GIDDENS, 1991; LIPOVETSKY, 2005). 
A religião no mundo moderno vem a ser (vir-a-ser), para alguns, uma dimensão ambivalente: fala de fundação e natureza, de um lado, e, de outro, joga-se nos braços tecnológicos do capitalismo midiático contemporâneo. Nem todas as narrativas religiosas supõem uma fundação além do mundo ou um transcendente (totalmente Outro, o outro totalmente).

A religião no mundo ocidental assumiu uma presença ontológica e metafísica, mas o Cristianismo (texto e letra do Mundo Ocidental ao longo de dois milênios), incorporou e dialogou com outras presenças: ameríndias, africanas, orientais e muitas outras. Essas transações semânticas não repercutiram no tradicional conceito fenomenológico de sagrado, formulado como anteparo ao pessimismo modernista, quiçá um soluço do romantismo idealista alemão.

No mundo moderno não é possível resumir a dimensão sacral a um tipo de vivência religiosa. Há tantas vivências pagãs, antigas e reconstruídas, populares e pós-modernas de religiosidades híbridas, esotéricas, afro-católicas, ibérico-católicas, afrodescendentes, florestais, camponesas, indígenas, lúdicas e agônicas. Há brincadeiras religiosas de ser e não ser, de estar ali e depois acolá, o que engana a muitos pesquisadores, que se posicionam como mais "crentes" do que os crentes "originais".

Por isso, em certas situações, fala-se em religiões, ou quiçá, nesses tempos desconcertantes, em espiritualidades. Dizem que é, enfim, o império do indivíduo desconectado das instituições, a dançar no espaço-tempo das cidades e do ciberespaço, consumindo e compondo sua própria sinfonia espiritual com notas consonantes e dissonantes, oriundas das mais diversas partituras religiosas. Um livre-indivíduo, compõe seus rituais e valores como quem senta à beira de um lago sábado à tarde, ou diante da tela azul de um computador, nas manhãs de segunda. O indivíduo e suas escolhas em amplitude máxima é uma imagem com ar romântico, e lembra Robson Crusoé. Mas, não seria essa imagem uma ideologia contemporânea, um desejo e um programa existencial?

Nos pés dos indivíduos, enroscam-se a instituição, as regras e as moralidades que pedem atenção exclusiva, pois são ciumentas: "Deus-Ciúme-Jeová" sucedido por "Deus-AmorMadalena" ou "Deus-Ternura-Filho-Pródigo". Arranjos e arcabouços institucionais e culturais entram em choque. Por isso, na modernidade contemporânea, emerge um espaço público atravessado por processos de encanto e desencanto, por emergências de minorias e sua luta por 
direitos, mas também por invenção de maiorias com destras autoritárias, mas ambas envazadas por diferentes concepções de sacralidades e profanidades.

As comunidades e instituições estão presentes e não desapareceram como em um passe de mágica, mas estão e se tornam (vir-a-ser), como nós, entroncamentos em uma rede de relações e fluxos, trânsitos, deslocamentos de corpos, ideias, valores e símbolos que elegem o indivíduo como a epítome do social e do sagrado. Nesse sentido, destaco a existência de três tipos de trânsitos: de pessoas entre tradições e símbolos, de práticas e crenças entre comunidades e grupos e de pessoas ao longo de sua vida, em sua trajetória biográfica, por religiosidades.

Os trânsitos de vontades, indivíduos, massas, corpos, signos e significantes acentua as crises na dimensão sacral, tornando-a um campo minado, cheio de riscos semânticos para os pesquisadores acadêmicos. Por conta dessas transações, as tradições religiosas teimam em reinventar-se na hipermodernidade: o sal grosso, a fita vermelha, a rosa branca, a água benzida e energizada, o gesto vigoroso a espantar maus augúrios, ou a agitar asas angelicais, novenas e correntes, inquebrantáveis, sacolas tilintando de dinheiro. Há uma confusão (ou uma comfusão) e, simultaneamente, uma diferenciação tensionada entre esferas de valor, tornando o campo conflagrado por lutas entre agências religiosas e não-religiosas em busca do capital social e simbólico.

Um outro problema atrelado à crise conceitual são os bordões fáceis que brotam de análises acadêmicas e das opiniões dadas ao "Deus-dará", ou doadas, de graça espargidas, aos borbotões ou aos solavancos empurradas, goela abaixo. Como falar do sagrado a partir de uma linguagem embotada, "dentro de botas" semânticas, aprisionadas em categorias, sendo que a cada nova jornada diária, as religiões conjugam verbos legislativos, enquanto outras ficam "aluaradas"? No trânsito moderno ou tradicional as formas de vida religiosa institucionais anseiam por sua perpetuação e jogam com as modernas transformações. O seguinte texto condensa as situações em que os conceitos de numinoso e sagrado encontram-se encurralados:

Santo Expedito, padroeiro da hipermodernidade. Talvez, nem tanto. Raios do Espírito Santo, de Fogo ou Ramatis em chamas violetas. Costeletas de Adão contra Darwin, totem sagrado de tribos ateias. Uma vela branca diante do busto de Kardec, Congás de diversos tamanhos e formas, estalos de dedos em unidades básicas de saúde. Ervas da mata, amazônica e outras: ancestrais conhecimentos em circulação e ressemantização; agentes populares e sábias mulheres, antigas e fortes. Ou, ainda, supostas memórias reencarnatórias desentranhadas no divã, na ponta do lápis diplomado. Candelabros 
legitimados diante do evangelho de Marcos. Pronúncias glossolálicas, às vezes em pés de frevo, pobres, frenéticos e negros, de mulher-pastora, ou de virgens que giram. Ou, os sussurros masculinos, brancos rosa-cruzes, de classe média. E dando mais duas pitadas: nas saias da cigana rosa-dourada, de renda ou no reluzente machado que ecoa pela pedreira: Xangố!

Como o conceito fenomenológico e sociológico de sagrado pode dar conta das atuais circulações de sentido entre as diversas dimensões sociais? Há pelo menos dois grandes conjuntos de tópicos semânticos que circulam entre as religiões no Brasil contemporâneo, com variações: dinheiro e prosperidade, de um lado, e, de outro, corpo, felicidade e bem-estar.

Conhecidos são os discursos e gestos dos líderes evangélicos neopentecostais exaltando a prosperidade e o dinheiro. Os rituais são criativos e as releituras da Bíblia se parecem com hermenêuticas pós-modernas. Por isso, não custa lembrar uma das míticas origens dessa teologia, a frase atribuída a um convertido ao evangelismo norte-americano e posteriormente participante de uma seita gnóstica cristã (Ciência Cristã): "O que eu confesso, eu possuo".

Nos espaços religiosos brasileiros, letras de música gospel, mantras hindus, pontos de umbanda, entre outros, expressam redefinições semânticas que enfatizam a alegria, o bem-estar, a superação do sofrimento e da dor, constituindo o corpo como índice e critério de espiritualização. O sagrado difundiu-se, dispersou-se, transmutou-se: é esse o de Rudolf Otto, o que fascina e atemoriza ao mesmo tempo?

Um mundo de sagrados tradicionais e clássicos foi dessacralizado, desconstruído, veio abaixo. Houve o desencantamento do mundo: no céu não há mais anjos e deuses ou deusas (WEBER, 2006). Ao mesmo tempo há multidões que creem nos renovados encantos da magia e do sagrado, ufólogos, pagãos pós-modernos em suas mais diversas ramificações e presenças.

Sagrado e dessacralização andam juntos nas sociedades pós-seculares: há espaço para múltiplas linguagens, a mítica, a científica, a acadêmica, a religiosa, a poética, a histórica. Por outro lado, o empecilho à compreensão entre grupos religiosos é a linguagem literal, o pé-daletra: se os grupos e os textos ficam com a literalidade, perde-se a dimensão das muitas linguagens humanas e a intolerância faz morada em gestos, pensamentos e presenças. O céu é da astronomia e dos deuses, deus, anjos, demônios, entidades, e, por isso, é possível dizer que o sagrado migrou por mil circuitos e lugares.

5 Texto anônimo. 
Um dos lugares é o corpo, imantado pelas sinestesias, visões, audições, sabores e humores dos mil cultos religiosos. Outro lugar é a prosperidade, noção que atinge outras searas, como as espíritas, herdeiras da desconfiança católica em relação ao lucro capitalista. Com títulos como "a senhora dos espíritos" ou "o império espírita", a revista Isto É entrevistou, em maio de 2013, a famosa médium Zíbia Gasparetto e fez uma provocativa pergunta sobre dinheiro e mediunidade. Ela respondeu: "O que essas pessoas têm contra o dinheiro? [...] O dinheiro é do mundo! E fica aqui. A gente responde pelo que faz com o dinheiro e eu estou fazendo bom uso dele". 6

As ideias de felicidade, bem-estar e cura são cotidianamente ditas e reditas, circulando em livros, canções, cultos e pregações de padres, pastores, lideranças umbandistas, candomblecistas, espíritas, new age, terapeutas esotéricos, entre outros.

Ser feliz é direito, mandato divino ou quase obrigação. Ser feliz é sagrado e sacros são os direitos do indivíduo; profana são as intervenções institucionais da norma religiosa na vida pessoal. Porém, do ponto de vista institucional, a relação se inverte: sagrados são os mandatos divinos, mediados pelos profetas, sacerdotes e magos; profanos são os desejos pessoais.

Alguns veem na multiplicação das sacralidades o recuo da grande teodiceia ocidental do sofrimento (CAMPBELL, 1997). Junto a esse recuo, ocorreria uma "orientalização" como reativação de correntes subalternas e subterrâneas de práticas e discursos religiosos gestados no Mundo Ocidental, mas impedidas de circularem pela preeminência das grandes narrativas cristãs e científicas (CAMPBELL, 1997).

Por outro lado, a ampla e crescente mixagem de gêneros estilísticos e pluralismos metodológicos nas academias e locais de produção do saber autorizado cientificamente indica que a circulação das linguagens do sagrado se encontra desterritorializada, ao mesmo tempo em que surgem reterritorializações do discurso, da linguagem e dos atores sociais.

Há constantes esforços para reterritorializar os marcos do discurso religioso, centralizando-os, se não em instituições, ao menos em ancoradouros, supostamente ao abrigo das flutuações retóricas e sociais trazidas pelas lutas e tensões que esta época contemporânea abriga e estimula.

6 Disponível em: <https://www.espiritismo.net/node/18038>. Acesso em: 27/05/2017. 
Assim, grupos religiosos cristãos (católicos e evangélicos) incrustam-se no aparelho estatal (legislativo, judiciário e executivo) e na sociedade civil, disseminando avaliações morais e lutando contra a suposta perda da memória ancestral do cristianismo e da ligação inextirpável, aos olhos conservadores, entre nação, ordem moral, família e direitos naturais. Uma sagrada ligação profanada na sociedade moderno-contemporânea.

Essa ligação inextirpável é um paradoxo, porque, nas religiões cristãs, as doutrinas de salvação pentecostais e neopentecostais são vistas como ponta de lança de uma identidade moderna e autocentrada: o indivíduo torna-se o lugar da batalha pela salvação, palco em que a transcendência divina digladia-se contra forças demoníacas, portanto, um santo lugar, morada do numinoso.

Por outro lado, nesse vasto panorama de intercruzamentos, os desdobramentos dos processos culturais no Brasil levam os pesquisadores a se perguntarem pela perenidade e coerência das tendências e imagens de sacralização do indivíduo e de suas escolhas: se no exorcismo, por exemplo, o culpado não é o indivíduo, mas o demônio, a desculpabilização é paradoxal, já que, pelos princípios da modernidade protestante clássica, a consciência e a responsabilidade são individuais.

Paralela à crescente importância da religião do self, que perpassa diversas religiosidades, principalmente após a crítica pós-moderna às grandes narrativas inseridas no fluxo da pulsão romântica, vicejam as tentativas de eclipsar as dualidades semânticas: corpo/mente, sociedade/indivíduo, sagrado/profano, ação/estrutura.

Contudo, afeições e desafeições cruzam céus institucionais, movendo fluxos de entrada, saída e permanência de grupos e indivíduos em determinados etos religiosos. Sagrado e profano em desconcerto, conectados pelos indivíduos.

É o caso da reação de católicos franceses diante de uma campanha, inflamada e radical, da Igreja Católica francesa contra o casamento gay. Alguns deles, homossexuais que viviam há anos com seus companheiros, afastaram-se e manifestaram raiva. Uma reportagem de 2013, veiculada por mídias como o Jornal Le Monde, abordou cidadãos e cidadãs francesas após essa campanha católica contra o casamento homossexual nas grandes cidades: 
Julien resistiu 'o máximo possível' e, depois, há dois meses, esse católico praticante não conseguiu mais. 'Eu deixei de ir à missa. Não aguentava mais paroquianos que distribuíam panfletos para a Manifestação para Todos Manif'. Recentemente, o jovem homossexual, unido ao seu companheiro há vários anos, deu um novo passo: 'Eu interrompi a minha transferência bancária automática em favor da Igreja'. Uma maneira radical de expressar a sua raiva contra a Igreja Católica, que, há nove meses, 'se mobilizou contra o casamento para todos, sem se preocupar com os homossexuais, mostrando um rosto profundamente excludente'. Depois que a lei foi aprovada e promulgada, muitos católicos se sentem cansados e esperam que a 'sua' Igreja saiba passar para outros temas. Outros católicos estão irritados para a continuidade das manifestações, em particular a do dia 26 de maio, e deploram 'a histerização dos debates'. E, depois de meses de unanimidade de fachada, alguns bispos estão começando a se preocupar com a politização e as divisões provocadas pelo assunto nas paróquias. ${ }^{7}$

A tensão entre concepções distintas de sagrado e profano aumenta quando discursos religiosos normativos, vocalizados por grupos políticos, pretendem fazer eco a uma "antiga obsessão do cristianismo latino: cimentar com precisão última, inalcançável e no final, autodestrutiva, as bases da autoridade final, imutável e inerrante. Seja ela a [...] decisão papal ou uma leitura literal da Bíblia" (TAYLOR, 2010, p. 601).

Dessa forma, as trajetórias dos indivíduos, grupos e comunidades bamboleiam entre a dureza do dogma e a radicalidade da hiperindividualização: desconfiança do indivíduo, suas emoções e seu self, por um lado; por outro, exaltação das singularidades e afetividades individuais e da certeza dada pela experiência pessoal de valores e de símbolos religiosos. Com isso, têm-se, de um lado, experiências de ultrapassagem, comunicação com o além (do corpo, da sociedade, do tempo e de si mesmo) e, de outro, o desejo de tradição, de sentir-se inserido em uma família venerável, num nobre passado.

Daí o caráter ambivalente do sagrado na religião ou nas religiões na modernidade contemporânea: centralidade da experiência e da emoção, engajamento do corpo e dos sentidos a partir de uma dimensão não institucional e individual, racionalidades modernas, mecanismos de garantia da segurança ontológica construídos a partir de uma realidade institucional e comunitária. De fato, na corrosão efetivada pelos poderes de solvência da modernidade, as buscas de fronteiras estão ativas e podem ser traduzidas como o esforço para sistematizar sensações e cognições flutuantes e individualizados, bem como diminuir os pontos de fuga de

\footnotetext{
7 A autoria é de Stéphanie Le Bars. Disponível em: <http://www.ihu.unisinos.br/noticias/520509-fieis-catolicos-feridos-pelareviravolta-identitaria-da-igreja $>$. Acesso em 27/05/2017.
} 
um sagrado disperso e opaco.

Há, de fato, dois movimentos. De um lado, o self sagrado, nas religiosidades new age e similares, totalidades porosas neorromânticas em redes de consumo e experimentação e, de outro, os selfs individuais, livres e rearranjados em novas comunidades de laços puramente religiosos, com vasta penetração nas religiosidades modernas racional-universalistas do tipo pentecostal e neopentecostal.

Cabe uma indagação: trata-se mesmo de linhas de demarcação definidas e certas? No self sagrado, para as espiritualidades orientais e new age, a religião reencontra-se com a ciência holística (as teorias quânticas que explicam toda relação possível entre o sagrado e a ciência) e a emoção é a via de acesso ao fenômeno, é garantia de autenticidade da experiência.

O consumo e a experiência social de produção de individualidades são articulados em redes, mas singulares em suas trajetórias e combinações individualizadas. São também desamarrados de institucionalidades e de cânones.

Ambos os movimentos se articulam em torno de outros centros de gravidade: comunidades de puro interesse religioso, em um caso, e redes de experimentação, em outro. Resta saber se ambos bebem das mesmas fontes de desterritorializações e se em ambos há combinação de traços neorromânticos e traços da reação ou da confirmação de fluxos de modernidade identitária.

Entre os pentecostais e neopentecostais, por exemplo, ocorre a desvinculação dos laços religiosos do passado, em meio ao afeto e às emoções realinhadas à busca de uma vida moralmente conservadora. Se, por um lado, a ética e a modernidade da religião universal de conversão individual são fundamentais, por outro, são importantes as emoções, as manifestações espirituais, os êxtases, os descendimentos do Espírito Santo, as revelações, os exorcismos desculpabilizadores (perda da centralidade do sujeito racional), as profecias (a voz do Outro, de Outros ou de Deus, através do eu), os cânticos, a oração em línguas e as danças.

Nem puro fulgor de destradicionalização, nem pura antropofagia à brasileira. É nesse entrelaçado que, na contemporaneidade brasileira, enredam-se o sagrado e as diversas ordens da existência sociorreligiosa. Por isso, a singularidade e a totalidade global das tendências modernas devem ser vistas como processo de articulação das diferenças.

Há diferenças, nesse sentido, entre o sagrado no mundo ocidental e aquele no mundo oriental? Pelas novas formas de comunicação (novas mídias), abriu-se uma janela para o 
Oriente, larga e espaçosa, um Oriente que penetra e compõe-se, em variados sincretismos, inclusive com o Cristianismo: yoga cristã que canta, no lugar de mantras, salmos alongados, graves e guturais. Por isso, as listagens de fenômenos crescem: a medicina chinesa, a acupuntura e outros procedimentos terapêuticos e de busca de iluminação interior se popularizam, expandem-se pelas cidades, são consumidos, propagam-se como ondas e recombinam-se entre si, ressemantizando a grande invenção ocidental, inaugurada por Santo Agostinho: o "eu" como interioridade, templo absoluto e sagrado, centro de decisão e escolha pessoal diante do Deus Todo-Poderoso.

Nos tempos contemporâneos, o "eu” pode escolher não ser "eu”, mas uma unidade com o "cosmo", um com o "todo" [homens e animais, plantas, universo: emanações e igualdades]. Para muitos tradicionalistas religiosos, vive-se um atentado contra as doxologias religiosas: $\mathrm{o}$ sagrado tem lugar, voz e vez e é veiculado pelas hierarquias religiosas. Para os que vivenciam essas experiências contemporâneas, há uma nova forma de viver a religião, ou melhor, a espiritualidade, categoria que ganhou enorme força nos discursos religiosos e acadêmicos com a migração dos sentidos do sagrado oriental para o mundo urbano ocidental.

A espiritualidade tornou-se, então, o novo refúgio do sagrado e, como conceito naturalizado, é usado em estudos empíricos dos supostos efeitos da religião no cérebro humano, por exemplo, ocupando o lugar de variável em estudos ditos científicos. Aqui o terreno se alarga tanto que as fronteiras vacilam e esmaecem. Tal categoria entrou também nas clínicas e na academia universitária (cursos de enfermagem), na ponta das agulhas da acupuntura, nas massagens terapêuticas e revigoradoras, e pode ser vocalizada por entidades de umbanda.

De fato, no mundo da modernidade tardia, os sentidos do sagrado pluralizam-se, competem e complementam-se, mas um deles ainda recebeu pouco destaque: o de brincar, o lúdico.

Há, por exemplo, velhos mitos que afirmam ser a dança dos deuses(as) a gênese da vida, da sociedade, do universo. Universos infinitamente belos e caóticos saem das traquinagens ou dos gozos e casos amorosos dos deuses e deusas. Um mito sufista, corrente mística do Islamismo nascida no século XIII na antiga Pérsia, atual Irã, tece uma bela imagem da criação: o universo inteiro, com todas as cores, ondas do mar e trovões celestes é criado enquanto Deus dança em giros e rodopios. Ao dançar, com gestos espalmados e girando sobre seu próprio eixo, de forma intensa, Deus faz brotar a vida, a criação nasce em esplendor. 
Mitos de deuses e deusas brincando não faltam na história dos povos e civilizações. Eros, na mitologia romano-latina, espeta com flechas os corpos dos amantes, que se entregam doidamente uns aos outros, às vezes, até a morte. Johan Huizinga (2008), ao falar sobre o jogo, mostra na história um significado pouco entendido das religiões e religiosidade: brincar é atividade lúdica de criação e invenção de novos mundos, papéis e possibilidades do real.

Pode-se afirmar que pequenos elementos da cultura, como as piadas, revelam boas pistas para pensar as diversas possibilidades de conexão entre o sagrado, o brincar, a invenção de novas realidades e o enfraquecimento da metafísica. Lembro-me de uma piada de humor sombrio que ouvi quando criança, contada por um vizinho mais velho. Ela falava de uma criança que brincava de espetar formigas com o alfinete, dizendo: "errei, poxa". Em determinado momento a criança é morta, fulminada. Por um raio. Lá do céu, ouve-se uma voz: "errei, poxa".

Por outro lado, a Bíblia, lócus do sagrado no Cristianismo, possui elementos de um brincar divino, sendo possível dizer que Deus tem humores, bons e maus: Javé transformou a mulher de Lot em estátua de sal e encarnou-se no seio de uma virgem, revelando-se como salvador. Deus brinca de contingência, poderiam dizer os filósofos amantes da ontologia, em sua tentativa de empoderar a metafísica ocidental diante dos formidáveis desafios lançados pelas modernas conquistas científico-tecnológicas.

Mircea Eliade (2002) diz que, desde o Neolítico até a Idade do Ferro, as descobertas tecnológicas e inovações socioeconômicas andavam de mãos dadas com cultos, ritos e manifestações do sagrado. Havia uma profunda ressonância religiosa das inovações e tecnologias, em especial no Oriente Próximo.

Naquela que talvez seja a cidade mais antiga do mundo, com cerca de 6.850 anos, encontraram-se em escavações arqueológicas muitos documentos (sentido largo do termo): estatuetas, representando o culto à feminilidade, e crânios enfeitados (ELIADE, 2002). Havia um culto interessante: enterrados sob o piso das casas, sofriam uma preparação singular: partes inferiores foram moldadas em gesso e os olhos feitos de conchas (ELIADE, 2002). Muitos vestígios de cultos agrários e palavras correlatas perduraram ao longo de milênios, não obstante a vigilância repressora de dois grandes monoteísmos: o cristianismo e o islamismo (ELIADE, 2002). Surgem vestígios reinventados sob a capa dura das instituições e autoridades religiosas, às vezes sob a forma lúdica: a do brincar para enganar o olhar do censor e para estabelecer novos sentidos do sagrado (ELIADE, 2002). 
Mas, nos tempos da alta modernidade capitalista, das altas inovações tecnológicas, das biotecnologias que alimentam antigos sonhos humanos (rejuvenescimento e imortalidade), muitos teólogos e autoridades eclesiásticas costumam ir às mídias e dizer: "o homem não deve brincar de Deus".

Caso Deus (deuses e deusas) possam brincar de ser homens e de criar mundos, ou de destruí-los num simples cruzar de dedos, o brincar de ser Deus (deuses e deusas, ou ainda o mundo) inspira sentimentos de vertigem e alegria. Essas transformações ocorrem a despeito dos líderes religiosos se aferrarem a modos reacionários e conservadores de interpretação da realidade sacral e não-sacral.

Nesse sentido, questões de amplas repercussões teológicas, antropológicas e sociais, inclusive para o enfraquecimento da metafísica, estão colocadas pelo jogo (e pelo brincar) de biohackers grinders ${ }^{8}$ [cientistas e amadores apaixonados por novas tecnologias que desejam melhorar o "código-fonte" dos humanos, o DNA, a chave da vida, e assim, brincar de Deus ou deuses(as)]. Em uma reportagem de 2016, um jornalista de Barcelona escreveu:

Oitenta e nove euros. Isso é tudo o que alguém necessita para converter-se em ciborgue. Ou, pelo menos, para fazê-lo com um kit que possibilita isso. Podes adquirir o kit pela internet e receberás em sua casa um chip do tamanho de um grão de arroz pré-carregado em uma seringa esterilizada, uma ampola para desinfetar a pele, algumas luvas cirúrgicas, gases e bandagens esterilizadas para cobrir a pequena ferida que ocorrerá quando o chip for implantado na mão (na membrana que existe entre os dedos polegar e indicador, caso as recomendações do vendedor sejam seguidas). Em dois anos foram vendidos mais de 10.000 kits, e se em princípio quem se interessava eram os aficionados por eletrônico, hoje o 'público é mais geral, de hackers e de apaixonados pela informática', como explica, por correio eletrônico, Amal Graafstra. (RIUS, 2016). ${ }^{9}$

\footnotetext{
Disponível em: <http://junq.info/wp-content/uploads/downloads/2015/07/Science-for-the-Masses.pdf>. Acesso em 27/05/2017.

9 Tradução livre do seguinte original: Ochenta y nueve euros. Eso es todo lo que uno necesita para convertirse en cíborg. $O$ al menos para hacerse con un kit que lo posibilita. Puede adquirirlo por internet y recibirá en su casa un chip del tamaño de un grano de arroz precargado en una jeringa estéril, una ampolla para desinfectar lapiel, unos guantes quirúrgicos, gasas y vendajes estériles para cubrir la pequeña herida que le quedará cuando selo implante en la mano (en la membrana que tiene entre los dedos pulgar e índice, si sigue las recomendaciones del vendedor). En dos años se han vendido más de 10.000 de estos kits, y si al principio sólo se interesaban por ellos los aficionados a la electrónica, en el último año los compradores son 'un público más general de hackers y aficionados a la informática', según explica vía correo electrónico Amal Graafstra (RIUS, 2016). Disponível em: <http://www.crg.eu/sites/default/files/crg_media/LAVAN161016044.PDF>. Acesso em: 27/05/2017.
} 
Em Nova York, alguns grupos de biohackers grinders se reúnem:

Em Nova York, eles se reúnem num grupo muito ativo, os Biohackers NYC, além de diversas startups, incubadoras e espaços de trabalho espalhados pelas partes menos nobres da cidade. O Biohackers NYC foi fundado no início de 2012. 'Nossa intenção vai da manipulação de genomas não-humanos até o corpo e a mente. Não importa o método, todos temos o potencial de nos tornarmos seres humanos de funcionamento ideal em sociedade. A pergunta é: como vamos chegar lá?', diz a psiquiatra e fundadora do grupo Lydia Fazzio. Na região do Brooklyn, um pequeno "biolaboratório comunitário" chamado Genspace hospeda cerca de uma dúzia de indivíduos realizando experimentos em biologia amadora envolvendo, por exemplo, a fusão de seres vivos com aparelhos eletrônicos. O laboratório oferece aulas abertas sobre biologia sintética, ou como produzir organismos vivos como se fossem máquinas. Carne de laboratório. A Crude Control, uma oficina realizada recentemente no Genspace, mostrou como carne e couro podem ser criados in vitro com engenharia de tecidos e explorou a possibilidade de desenvolver "produtos" semivivos a partir deles. Apesar da oficina ter objetivos educacionais, tecnologias semelhantes já estão entrando no mercado: o investidor Peter Thiel, por exemplo, colocou centenas de milhares de dólares em uma startup que pretende disponibilizar comercialmente carne in vitro produzida por impressoras 3D. ${ }^{10}$

No caudal de novos sentidos do sagrado na modernidade contemporânea, é possível mencionar também a arte biotecnológica, ou seja, a arte de criar novas formas de vida por puro prazer estético e lúdico. Há, nesses trans-humanismos, uma dessacralização semânticosimbólica da última fronteira do sagrado, do ontológico e do metafísico: o humanismo, que balizou no mundo ocidental moderno as propostas e reflexões de grande parte das tradições epistemológicas.

Por isso, adianta falar de profanações diante dessas misturas de realidades vivas e meios eletrônicos? O brincar de Deus parece ser uma fonte de novas possibilidades que ultrapassam as velhas questões colocadas pelo humanismo desde o Renascimento e o Iluminismo. O sonho da fusão, ou confusão, entre humanidade, divindade e eletrônica, continua:

Dois sites populares sobre o tema reúnem biohackers de todo o mundo. $\mathrm{Na}$ página diybio.org, é possível encontrar iniciativas como a BioArt Laboratories, uma organização holandesa cujos participantes criam arte e música com culturas celulares e materiais biológicos. No biohack.me, os usuários contemplam as possibilidades de criar fones de ouvido por condução óssea e implantes de ecolocação (que permitiriam detectar a distância de objetos por meio de ondas, uma espécie de imitação do sentido "sonar" do morcego). [...]. Essas tecnologias não são apenas algo que nos aguarda no futuro: elas já estão sendo monetizadas e comercializadas em massa. Aparelhos de leitura de ondas cerebrais como o Emotiv e o Mindwave, por exemplo, já são usados para substituir o controle em jogos que passam a ser comandados com o pensamento. Criar um software para esses aparelhos é

\footnotetext{
${ }^{10}$ Disponível em: <http://revistagalileu.globo.com/Revista/Common/0,EMI322846-17579,00OS+BIOHACKERS+ESTAO+CHEGANDO.html>. Acesso em: 27/05/2017.
} 
mais ou menos tão complexo quanto criar um aplicativo de smartphone. Em outras palavras, em 20 ou 30 anos, provavelmente pensaremos nas comunidades biohackers da mesma forma que pensamos no Vale do Silício da década de 70 ou em Harvard nos anos 90: épocas em que amadores [...] e pequenos empresários construíram [...] projetos que levaram à fundação de empresas como Apple, Google e Facebook. ${ }^{11}$

Parece que o desejo de um "além-do-homem" ou de mesclar traçados e desnaturalizar supostas naturezas fixas é a sombra inspiradora dos projetos que procuram fundir homens e máquinas. Nesse aspecto, vale a pena citar Nietzsche (1995, p. 49-50):

Neste mundo, só o jogo do artista e da criança tem um vir à existência e um perecer, um construir e um destruir sem qualquer imputação moral em inocência eternamente igual. E, assim como brincam o artista e a criança, assim brinca também o fogo eternamente ativo, constrói e destrói com inocência - e esse jogo joga-o o Eão (Aiôn) consigo mesmo.

É preciso pensar também o sagrado a partir de uma filosofia política do poder. O sagrado foi inextrincavelmente atrelado às condições morais no mundo ocidental cristão. Destaca-se aqui a sutil associação entre sacro e soberano no seio do Cristianismo. A soberania divina onipotente é simultaneamente amoral e criadora da moral. O paradoxo evidencia-se nas Escrituras Sagradas Cristãs (Êxodos), quando se pensa, por exemplo, sobre a praga lançada por Jeová contra o Faraó [a morte dos primogênitos de toda criatura viva, por um anjo] ou, ainda, sobre a estranha ação divina de endurecimento do coração: "Moisés e Arão realizaram todos esses prodígios diante do faraó, mas o Senhor lhe endureceu o coração, e ele não quis deixar os israelitas saírem do país" (ÊXODOS, 11, versículo 10). ${ }^{12}$

Na filosofia nietzschiana, os artistas e as crianças são similares ao demiurgo e ao criador onipotente: sem imputação moral e com inocência original, sem a carga moral da culpa, do ressentimento, da moral dos escravos, que faz decair a liberdade de ser e existir.

Mas, o sagrado, como potência soberana, termina na modernidade moderna ou na contemporânea? Nada há no panorama político-econômico que remeta aos rastros do sagrado? Para Agamben (2011), não deixou de existir uma presença contínua entre teologia e política por

\footnotetext{
${ }^{11}$ Disponível em: <http://revistagalileu.globo.com/Revista/Common/0,EMI322846-17579,00OS+BIOHACKERS+ESTAO+CHEGANDO.html>. Acesso em: 27/05/2017.

${ }^{12}$ Disponível em: <https://www.bibliaon.com/a_morte_dos_primogenitos/>. Acesso em: 27/05/2017.
} 
meio da ideia de sacro e soberania no mundo ocidental contemporâneo.

O poder político no mundo moderno erigiu-se sobre a aclamação e a glória, originalmente ligadas à liturgia cristã (AGAMBEN, 2011). Por isso, a compreensão dos dispositivos de aclamação do mundo político contemporâneo remete ao questionamento dos sentidos de democracia e de como os modernos conceberam esta forma de exercício do poder político (AGAMBEN, 2011). Portanto, a compreensão do sagrado não pode ser dissociada da ideologia e das políticas de poder, que são parte indissociável das comunidades religiosas e das comunidades científico-acadêmicas.

A soberania popular tornou-se refúgio do conceito do sagrado, e a democracia das modernas sociedades contemporâneas viveu o ápice. Todavia o moderno ecossistema midiático-digital suscitou configurações que abalaram os alicerces da representação do real, da ação política e da liberdade, que foram, em última instância, produtos de antigas migrações semânticas entre a liturgia cristã e o Estado moderno.

A essas configurações da vida contemporânea é possível acrescentar a luta entre a teodiceia ocidental e a oriental (quiçá um sagrado oriental e ocidental), menos como produtos espaciais e mais como duas tendências em contraponto: "ocidentalização" [expansão planetária do modelo socioeconômico e político de civilização ocidental moderna, industrial, etc.] e “orientalização" [expansão planetária de outras fontes de significação do cosmos, do humano e de suas relações] (CAMPBELL, 1997).

Dois dos mais poderosos sistemas intelectuais, o Cristianismo e o Progressismo Secular (Socialismo e Marxismo), sofreram suas mais fortes críticas e reveses após a queda do muro de Berlim, em 1989 (CAMPBELL, 1997). As duas "grandes tradições mostraram sinais claros de mudança em direção a um paradigma oriental, sendo a influência imediata principal, em ambos os casos, não o pensamento oriental, mas a filosofia idealista alemã” (CAMPBELL 1997, p. 17). 
Por fim:

É no próprio coração do Ocidente que a 'ocidentalização' está enfrentando seu desafio mais selvagem, um desafio que está sendo suportado por uma perspectiva que é, em essência, 'oriental'. Isso está ocorrendo porque aquele paradigma dominante ou 'teodicéia' que serviu tão efetivamente ao Ocidente por dois mil anos finalmente perdeu seu controle sobre a maioria da população na Europa Ocidental e na América do Norte. Essas não sustentam mais uma visão de mundo dividido em matéria e espírito e governado por um Deus criador, pessoal e todo-poderoso, que tenha colocado suas criaturas acima do resto da criação. Essa visão foi abandonada e, com ela, toda justificativa em favor do domínio do homem sobre a natureza. Em seu lugar foi posta a visão fundamentalmente oriental da humanidade como parte da entrelaçada teia de vida espiritual e sensitiva (CAMPBELL, 1997, p. 20).

Os movimentos ambientalistas, a ressurgência de discursos e visões de mundo "nativos" e marginalizados (povos indígenas, xamanismos, combinações religiosas, como umbandaime e muitos outros exemplos) tomam pujança e implodem a teodiceia cristã do Ocidente, um dos mais tradicionais portos seguros do sagrado ocidental, enquanto ontologia do ser.

Com as perturbações no conceito de sagrado, pode-se pensar que a tarefa de conceituar, vista como a mais fundamental para a compreensão moderno-científica, torna-se extenuante, porque os contornos dos objetos empíricos nunca são nítidos o bastante, embora os conceitos formais sejam vistos como aclaradores das realidades religiosas e espirituais. Mas, à medida que a conceituação define zonas claras e delimitadas, surgem fenômenos que desestabilizam as fronteiras, e uma nova tarefa de repensar os conceitos se inicia. Por entre os dedos do conceito, o líquido do sagrado, da religião, da modernidade e do religioso escapa constantemente. A partir de uma perspectiva pós-estruturalista, o ato de conceituar é exercício de poder que demarca territórios semânticos, e, com isto, a transgressão de fronteiras, nascem os pré-conceitos. Talvez seja possível opor à noção de conceito a noção de narrativa, mais aberta e porosa, mas com não menos rigor intelectual e compreensivo. Mas isso é tarefa para outro texto, em outra oportunidade de reflexão. 


\section{Referências}

AGAMBEN, G. O reino e a glória: uma genealogia teológica da economia e do governo. São Paulo: Boitempo, 2011.

DURKHEIM, E. As formas elementares da vida religiosa. São Paulo: Martins Fontes, 2006.

ELIADE, M. História das ideias e crenças religiosas. Da Idade das Pedras aos Mistérios de Eleusis. Volume I. Porto: Rés Editora, 2002.

CAMPBELL, C. A orientalização do Ocidente: reflexões sobre uma nova teodicéia para um novo milênio. Religião e sociedade, Rio de Janeiro, vol. 18, n. 1, agosto de 1997, p. 5-22.

FOUREZ, G. A construção das ciências. Introdução à filosofia da ciência e a ética das ciências. São Paulo: Editora da Universidade Estadual Paulista, 1995.

GIDDENS, A. As consequências da modernidade. São Paulo: UNESP, 1991.

HERVIEU-LEGER, D. La Religion pour mémoire. Paris, Le Cerf, 1993.

HUIZINGA, J. Homo Ludens. O jogo como elemento da cultura. São Paulo: Editora Perspectiva, 2008.

LIPOVETSKY, G. A sociedade pós-moralista. Crepúsculo do dever. São Paulo: Editora, 2005.

NIETZSCHE, F. A filosofia na Idade Trágica dos Gregos. Lisboa: Edições 70, 1995.

OTTO, R. O Sagrado: um estudo do elemento não-racional na ideia do divino e a sua relação com o racional. São Bernardo do Campo: Imprensa Metodista, 1985.

TAYLOR, C. Uma era secular. São Leopoldo: UNISINOS, 2010.

USARSKI, F. Os enganos sobre o Sagrado. Uma síntese da crítica ao ramo "clássico" da fenomenologia da religião e seus conceitos-chave. REVER - Revista de Estudos da Religião, São Paulo, no 4, 2004, p. 73-95.

WEBER, M. Sociologia das Religiões. Considerações intermediárias. Lisboa: Relógio D’Água Editores, 2006. 